\title{
ANALISIS NILAI TAMBAH GULA KELAPA DI DESA SIALANG JAYA KECAMATAN BATANG TUAKA KABUPATEN INDRAGIRI HILIR
}

\author{
Nina Sawitri ${ }^{1}$, Yuslizar ${ }^{1}$ \\ ${ }^{1}$ Prodi Agribisnis, Fakultas Pertanian, Universitas Islam Indragiri \\ Email: yuslizarfaaiq@gmail.com (korespondensi)
}

\begin{abstract}
Coconut sugar processing is one of the agro-industry businesses that is developing in Sialang Jaya Village, Batang Tuaka District, Indragiri Hilir Regency. This business aims to obtain added value from coconut plants. The purpose of this study was to determine the amount of revenue and profits from the coconut sugar processing business and the added value of the coconut sugar processing business in Sialang Jaya Village, Batang Tuaka District, Indragiri Hilir Regency. Analysis of the data used is the analysis of costs, revenues, profits and added value. The results of this study indicate that: (1) The average total cost of the coconut sugar processing business is Rp. 67,351.97 per production, the average revenue is $R p$. 202,800.00 per production, the average profit is Rp. $135,448.03$ per production. (2) The added value obtained in the coconut sugar processing business is $R p .4,672.76$. The added value ratio obtained is $83.87 \%$. The profit from processing coconut sugar is $R p$. 3,024.41 per $\mathrm{kg}$ with a profit rate of $64.72 \%$.
\end{abstract}

Keywords: coconut sugar, revenue, profit, added value

\begin{abstract}
Abstrak
Pengolahan gula kelapa merupakan salah satu usaha agroindustri yang berkembang di Desa Sialang Jaya Kecamatan Batang Tuaka Kabupaten indragiri Hilir. Usaha ini bertujuan untuk memperoleh nilai tambah dari tanaman kelapa. Tujuan penelitian ini adalah untuk mengetahui besarnya penerimaan dan keuntungan usaha pengolahan gula kelapa dan besarnya nilai tambah usaha pengolahan gula kelapa di Desa Sialang Jaya Kecamatan Batang Tuaka Kabupaten Indragiri Hilir. Analisis data yang digunakan adalah analisis biaya, penerimaan, keuntungan dan nilai tambah. Hasil penelitian ini menunjukan bahwa: (1) Rata-rata biaya total pada usaha pengolahan gula kelapa sebesar Rp. 67.351,97 per produksi, rata-rata penerimaan sebesar Rp. 202.800,00 per produksi, rata-rata keuntungan sebesar Rp. 135.448,03 per produksi. (2) Nilai tambah yang diperoleh pada usaha pengolahan gula kelapa sebesar Rp. 4.672,76. Rasio nilai tambah yang diperoleh adalah sebesar 83,87 \%. Keuntungan dari pengolahan gula kelapa adalah sebesar Rp. 3.024,41 per kg dengan tingkat keuntungan $64,72 \%$.
\end{abstract}

Kata kunci: gula kelapa, penerimaan, keuntungan, nilai tambah

\section{PENDAHULUAN}

Kecamatan Batang Tuaka merupakan salah satu Kecamatan di Kabupaten Indragiri Hilir, dimana di Kecamatan tersebut memiliki jumlah pengusaha gula kelapa yang cukup banyak salah satu desa yg ada di Kecamatan Batang Tuaka yaitu Desa Sialang Jaya. Di Desa Sialang Jaya banyak tumbuh dan berkembang tanaman buah kelapa yang dibudidayakan oleh masyarakat sekitar untuk pembuatan gula kelapa, selain itu tanaman kelapa juga dimanfaatkan untuk diambil buahnya dijual dan produksi kopra.

Industri gula kelapa yang berada di Desa Sialang Jaya merupakan industri berskala rumah tangga, dimana penggunaan tenaga kerjanya yaitu tenaga kerja dalam keluarga. Industri gula kelapa di Desa Sialang Jaya telah ada berlangsung secara turun temurun dan masih bersifat tradisional, baik dalam proses produksi maupun pemasarannya. Namun pendapatan dari industri gula kelapa 
ini mampu memberikan kontribusi yang cukup besar.

Produsen gula kelapa yang ada di Desa Sialang Jaya belum memperhatikan manajemen usaha, terutama yang berkaitan dengan besarnya biaya, penerimaan, dan keuntungan usaha. Sehingga perlu dilakukan analisis untuk menghitung berapa penerimaan dan keuntungan usaha yang dapat diperoleh petani. Adanya usaha pengolahan gula kelapa tentunya diharapkan mampu meningkatkan nilai tambah dari buah kelapa sehingga akan meningkatkan pendapatan petani kelapa. Sehubungan dengan permasalahan tersebut maka perlu dicari solusi untuk mengkaji berapa nilai tambah yang diperoleh petani dari usaha pengolahan gula kelapa. Berdasarkan latar belakang tersebut maka tujuan penelitian ini adalah untuk mengetahui besarnya penerimaan dan keuntungan usaha pengolahan gula kelapa dan besarnya nilai tambah usaha pengolahan gula kelapa di Desa Sialang Jaya Kecamatan Batang Tuaka Kabupaten Indragiri Hilir.

\section{TINJAUAN PUSTAKA}

\subsection{Gula Kelapa}

Gula kelapa atau dikenal juga sebagai gula jawa yang dihasilkan dari penguapan nira pohon kelapa (Cocos Nucifer L). Nira adalah cairan manis yang diperoleh dengan melakukan penyadapan terhadap bunga kelapa (mayang) yang belum membuka pada stadia umur tertentu.

Gula kelapa adalah bahan pemanis yang merupakan hasil olahan nira yang sejak dahulu hingga saat ini merupakan bahan perdagangan yang penting bagi rakyat di pedesaan (Setyamidjaja, 1984). Nira adalah cairan bening yang terdapat didalam mayang kelapa yang pucuknya belum dibuka.

Nira didapatkan dengan penyadapan atau penderesan. Satu buah mayang dapat disadap selama 10-35 hari tergantung kondisi pohon kelapa, namun produksi optimal hanya 15 hari. Hasil yang diperoleh sekitar 0,5-1 liter nira setiap mayang,atau sekitar 2-4 liter nira per pohon setiap harinya.

Ada beberapa faktor yang mempengaruhi banyaknya nira yang diperoleh, salah satunya adalah iklim. Penyadapan yang dilakukan pada musim penghujan akan mendapatkan nira lebih banyak daripadamusim kemarau. Menurut pengakuan penyadap, bahwa hasil penyadapan dua mayang pada musim penghujan sama dengan tiga mayang pada musim kemarau.

[9] Gula kelapa cukup kaya karbohidrat dan unsur protein serta mineralnya. Secara lengkap, kadar gizi yang terkandung dalam gula kelapa dapat dilihat pada tabel 1 .

Tabel 1. Komposisi zat gizi gula Kelapa per 100 gram bahan.

\begin{tabular}{|c|c|c|}
\hline No & Zat Gizi & Jumlah \\
\hline 1. & Kalori & $386 \mathrm{Kal}$ \\
\hline 2. & Karbohidrat & $76 \mathrm{gr}$ \\
\hline 3. & Lemak & $10 \mathrm{gr}$ \\
\hline 4. & Protein & $3 \mathrm{gr}$ \\
\hline 5. & Kalsium & $76 \mathrm{mg}$ \\
\hline 6. & Fosfor & $37 \mathrm{mg}$ \\
\hline 7 & Air & $10 \mathrm{gr}$ \\
\hline
\end{tabular}

Sumber : Santoso H.B, 1995

\subsection{Produksi}

Produksi adalah menciptakan, menghasilkan, dan membuat. Kegiatan produksi tidak akan dapat dilakukan kalau tidak ada bahan yang memungkinkan untuk melakukan proses produksi itu sendiri. Untuk bisa melakukan produksi, orang memerlukan tenaga manusia, sumber-sumber alam, modal dalam segala bentuknya, serta kecakapan. Semua unsur itu disebut faktorfaktor produksi (factors of production). Suatu proses produksi dapat berjalan jika adanya faktor produksi dan sarana produksi. Faktor produksi adalah faktor yang mutlak diperlukan dalam proses produksi, sedangkan sarana produksi adalah sarana yang dibutuhkan dalam faktor produksi.

Proses produksi dalam pertanian lebih di kenal dengan budidaya tanaman merupakan proses usaha bercocok tanam/budi daya di lahan untuk menghasilkan bahan segar (raw material). Bahan segar tersebut dijadikan bahan baku untuk menghasilkan bahan setengah jadi (work in proses) atau barang jadi (finised produk) di industri-industri pertanian atau dikenal dengan nama agroindustri atau agrifood industry [8].

Produksi adalah usaha atau kegiatan manusia untuk menciptakan atau menimbulkan kegunaan suatu benda agar menjadi lebih berguna bagi pemenuhan kebutuhan manusia. Dari definisi ini jelas bahwa untuk memenuhi kebutuhan haruslah lebih dahulu melakukan berbagai kegiatan. Kegiatan-kegiatan tersebut bertujuan untuk menghasilkan, menciptakan, mengolah barang atau jasa, dan meningkatkan atau menciptakan kegunaan suatu benda agar memiliki nilai guna lebih tinggi bagi pemenuhan kebutuhan. 


\subsection{Biaya Produksi}

Biaya produksi terdiri dari biaya tetap dan biaya variabel. Biaya tetap adalah biaya yang jumlahnya tidak bergantung pada perubahan jumlah produksi, misalnya biaya penyusutan peralatan. Biaya variabel adalah biaya yang dipengaruhi oleh kapasitas produksi. Semakin besar kapasitas produksi maka semakin besar biaya yang dibutuhkan dan sebaliknya.

Biaya produksi [7] merupakan biaya-biaya yang terjadi untuk mengolah bahan baku menjadi produk jadi yang siap untuk dijual. Biaya Produksi dapat meliputi unsur-unsur sebagai berikut yaitu bahan baku atau bahan dasar termasuk bahan setengah jadi, bahanbahan pembantu atau penolong, upah tenaga kerja, penyusutan peralatan produksi, uang, modal, sewa, biaya penunjang seperti biaya angkut dan biaya listrik seta pajak.

Biaya dalam pengertian ekonomi adalah semua beban yang harus ditanggung untuk menyediakan barang yang siap dipakai konsumen. [12] Biaya usahatani dapat di klasifikasikan menjadi dua yaitu biaya tetap dan biaya variabel. Biaya tetap (Fixed Cost) adalah biaya yang relatif tetap jumlahnya dan harus dikeluarkan walaupun produk yang dihasilkan banyak atau sedikit, misalnya PBB, biaya sewa gedung dan lain sebagainya. Biaya tidak tetap (Variable Cost) adalah biaya tidak tetap yang sifatnya berubah-ubah tergantung dari besar kecilnya produksi yang dihasilkan, misalnya dalam hal ini adalah nira kelapa yang akan dijadikan gula juruh dan lainnya.

\subsection{Penerimaan}

[12] Penerimaan adalah perkalian antara produksi yang diperoleh dengan harga jual dan biasanya produksi berhubungan negatif dengan harga, artinya harga akan turun ketika produksi berlebihan.

Semakin banyak jumlah produk yang dihasilkan maupun semakin tinggi harga per unit produksi yang bersangkutan, maka penerimaan total yang diterima produsen akan semakin besar. Sebaliknya jika produk yang dihasilkan sedikit dan harganya rendah maka penerimaan total yang diterima produsen semakin kecil [11].

Penerimaan total/pendapatan kotor adalah jumlah seluruh penerimaan dari hasil penjualan sejumlah produk (barang yang dihasilkan). Cara untuk menghitung penerimaan total dapat dilakukan dengan mengalikan jumlah produk dengan harga jual produk per unit. Hasil perkalian tersebut adalah total penerimaan yang diterima atau biasa disebut pendapatan kotor. Total penerimaan juga dapat didefinisikan sebagai nilai uang yang diterima dari penjualan.

\subsection{Keuntungan}

[5] Keuntungan adalah selisih antara pendapatan yang diterima dari penjualan dengan biaya kesempatan dari sumberdaya yang digunakan. [14] Keuntungan (Pendapatan bersih) adalah selisih lebih pendapatan atas beban sehubungan dengan usaha untuk memperoleh pendapatan tersebut selama periode tertentu.

Pendapatan bersih yang diperoleh yaitu dengan mengurangi pendapatan total dengan biaya total. TR adalah pendapatan total dari penjualan jumlah produk yang dihasilkan (jumlah produk dikalikan harga yang berlaku).

\subsection{Nilai Tambah}

Nilai tambah adalah penambahan nilai suatu komoditas karena mengalami proses pengolahan, pengangkutan ataupun penyimpanan dalam suatu produksi. Dalam proses pengolahan nilai tambah dapat di definisikan sebagai selisih antara nilai produk dengaan nilai biaya bahan baku dan input lainnya, tidak termasuk tenaga kerja. Analisis nilai tambah pengolahan produk pertanian dapat dilakukan dengan cara sederhana, yaitu melaluai perhitungan nilai tambah per kilogram bahan baku untuk satu kali pengolahan yang menghasilkan produk tertentu [3].

[15] Nilai tambah dapat diciptakan melalui cara Pengembangan teknologi baru (develoving new technology), Penemuan pengetahuan baru (discovering new knowledge), Perbaikan produk (barang dan jasa) yang sudah ada (improving existing products or services) dan Penemuan caracara yang berbedauntuk menghasilkan barang dan jasa yang lebih banyak dengan sumber daya yang lebih sedikit (finding different ways of providing more poods and services with fewer resources).

Nilai tambah di dapat dari besarnya nilai akhir dari produksi industri pengolahan kelapa menjadi kopra dikurangi dengan besarnya nilai bahan baku, nilai bahan penolong dan sumbangan input lain. Penghitungan nilai tambah di gunakan metode hayami.

\section{METODOLOGI PENELITIAN}

\subsection{Waktu dan Tempat Penelitian}

Penelitian ini dilakukan di Desa Sialang Jaya Kecamatan Batang Tuaka Kabupaten 
Indragiri Hilir. Penentuan lokasi penelitian ini dipilih secara sengaja (purposive) dengan pertimbangan bahwa wilayah tersebut memiliki banyak produsen gula kelapa di Kecamatan Batang Tuaka. Penelitian ini dilakukan selama kurang lebih 3 bulan yaitu pada bulan November sampai dengan bulan Januari 2018.

\subsection{Jenis dan Sumber Data}

Sumber data yang diperlukan pada penelitian ini adalah:

1. Data Primer di peroleh dengan cara melakukan wawancara kepada pedagang yang melakukan usaha pengolahan santan kelapa yang ada di Kecamatan Tembilahan dengan panduan pertanyaan yang sudah disiapkan meliputi identitas responden, produksi yang dihasilkan, pendapatan dan sebagainya.

2. Data Sekunder diperoleh dari instansi (lembaga) yang terkait diantaranya berasal dari Badan Pusat Statistik, data Dinas Koperasi dan UKM Kabupaten Indragiri Hilir.

\subsection{Metode Pengambilan Sampel}

Populasi dalam penelitian ini adalah pengrajin gula kelapa yang berproduksi di Desa Sialang Jaya Kecamatan Batang Tuaka yaitu sebanyak 112 Orang, dari jumlah populasi tersebut dapat diambil sampel sebanyak 30 \% sehingga di peroleh sampel sebanyak 25 Orang pengrajin gula kelapa. Metode yang digukan untuk menentukan jumlah sampel yaitu dengan menggunakan metode (Random Sampling) yaitu dengan pengambilan sampel secara acak.

\subsection{Metode Analisis Data}

Untuk mengetahui total biaya produksi secara sistematis dirumuskan sebagai berikut:

\subsubsection{Biaya Total}

Biaya total dihitung dengan menggunakan rumus:

Dimana :

$$
\mathrm{TC}=\mathrm{FC}+\mathrm{VC}
$$

$$
\begin{array}{ll}
\text { TC } & =\text { Biaya Total }(\mathrm{Rp} / \text { produksi) } \\
\text { FC } & =\text { Biaya Tetap }(\mathrm{Rp} / \mathrm{produksi}) \\
\text { VC } & =\text { Biaya Variabel }(\mathrm{Rp} / \text { produksi) }
\end{array}
$$

\subsubsection{Penyusutan Alat}

Untuk menghitung biaya penyusutan alat dihitung dengan metode garis lurus menurut dengan rumus sebagai berikut:

$$
D=\frac{C-S V}{U L}
$$

Dimana :

$$
\begin{array}{ll}
\text { D } & =\text { Nilai penyusustan alat } \\
\text { C } & =\text { Harga beli alat } \\
\text { SV } & =\text { Nilai sisa }(20 \% \times \text { nilai beli }) \\
\text { UL } & =\text { Masa pakai }
\end{array}
$$

\subsubsection{Analisis Penerimaan}

Penerimaan adalah perkalian antara produksi yang dihasilkan dengan harga jual dan biasanya produksi berhubungan negatif dengan harga, artinya harga akan turun ketika produksi berlebihan [13]. Penerimaan dapat dihitung dengan menggunakan rumus sebagai berikut :

$$
\mathrm{TR}=\mathrm{Q} \times \mathrm{P}
$$

Keterangan :

$\mathrm{TR}=$ Penerimaan Total $(\mathrm{Rp} /$ produksi)

$\mathrm{Q}=\operatorname{Jumlah}(\mathrm{Kg} /$ produksi)

$\mathrm{P}=$ Harga (Rp/produksi)

\subsubsection{Keuntungan}

Keuntungan (Pendapatan bersih) adalah selisih lebih pendapatan atas beban sehubungan dengan usaha untuk memperoleh pendapatan tersebut selama periode tertentu. Dapat ditulis dengan rumus sebagai berikut :

$$
\pi=\mathrm{TR}-\mathrm{TC}
$$

Dimana:

$\pi=$ Pendapatan Bersih (Rp/produksi)

$\mathrm{TR}=$ Penerimaan Total $(\mathrm{Rp} /$ produksi)

$\mathrm{TC}=$ Biaya Total $(\mathrm{Rp} /$ produksi $)$

\subsubsection{Pendapatan Kerja Keluarga}

[4] Untuk menghitung pendapatan keluarga digunakan rumus sebagai berikut:

$$
\mathrm{PKK}=\pi+\mathrm{TKDK}+\mathrm{D}
$$

\section{Keterangan :}

$$
\begin{aligned}
\text { PKK }= & \text { Pendapatan kerja keluarga } \\
\pi & =\text { Keuntungan (Rp/produksi) } \\
\pi & \text { Upah tenaga kerja dalam keluarga } \\
\text { TKDK }= & \quad \text { Rp/produksi) } \\
D \quad= & \text { Penyusutan alat (Rp/produksi) }
\end{aligned}
$$

\subsubsection{Analisis Nilai Tambah}

Nilai tambah merupakan nilai yang ditambahkan kepada barang dan jasa yang dipakai oleh unit produksi dalam proses produksi sebagai biaya antara. Nilai yang ditambahkan ini sama dengan balas jasa atas ikut sertanya faktor produksi dalam proses produksi. Perhitungan nilai tambah usaha kelapa menjadi kopra bertujuan untuk mengetahui penambahan nilai dari proses pengolahan bahan baku menjadi kopra. Nilai tambah di hitung dari delisih antara nilai output (penerimaan) dan nilai input (biaya 
total) yang di keluarkan dalam proses pengolahan. Perhitungan nilai tambah digunakan metode hayami, yang dihitung menggunakan tabel 2 .

Tabel 2. Metode Perhitungan Nilai Tambah Produk Turunan Kelapa

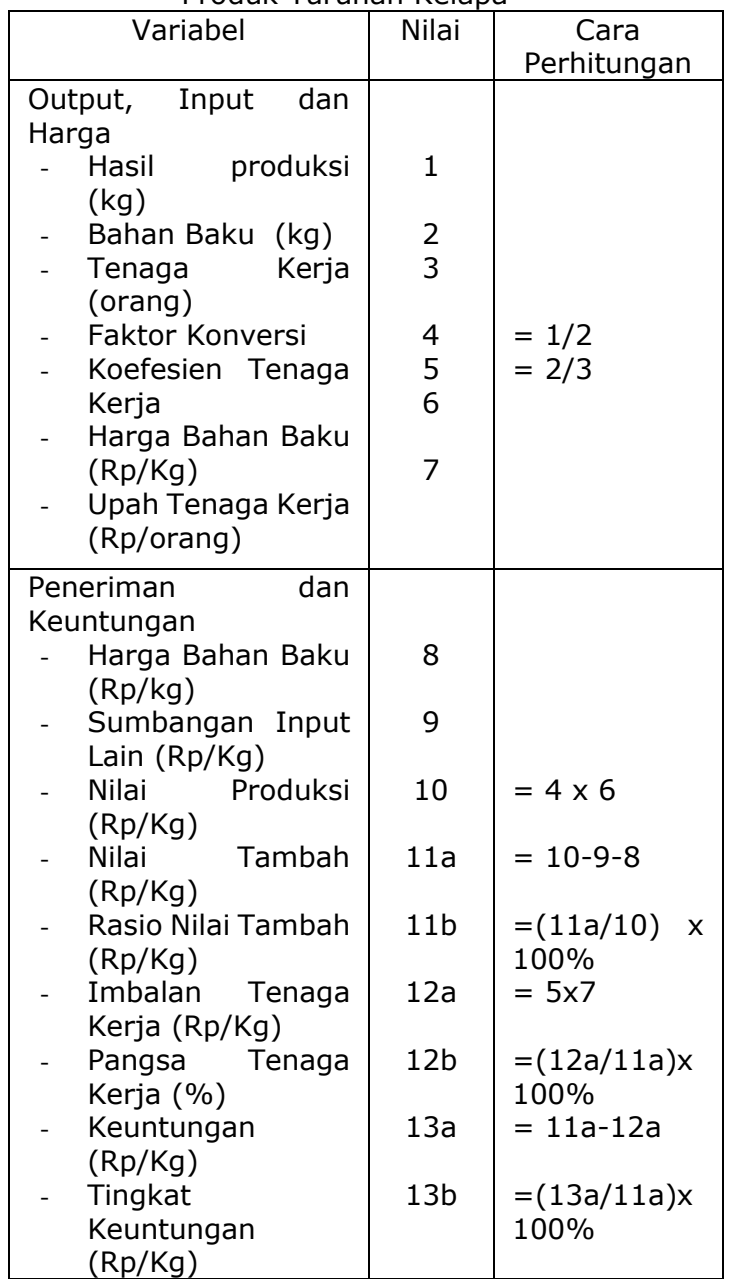

Sumber : Hayami, 1987

\section{HASIL DAN PEMBAHASAN}

\subsection{Karakteristik Responden}

\subsubsection{Responden Berdasarkan Umur}

[12] Dari segi umur petani yang berumur lebih muda akan akan lebih berani menghadapi resiko dan lebih cepat dalam menerima informasi dan tehnologi baru. Hal ini didukung pula oleh pendapat Hernanto [4] yang menyatakan bahwa semakin tua umur petani maka pertimbangan dan pengambilan keputusan relatif lebih lama dibandingkan petani yang lebih muda. Kategori umur responden disajikan pada tabel 3.

Tabel 3. Kategori Umur Responden di Desa Sialang Jaya Kecamatan Batang Tuaka Kabupaten Indragiri Hilir

\begin{tabular}{|c|c|c|c|}
\hline No & Umur & Jumlah & $\begin{array}{c}\text { Persentase } \\
(\%)\end{array}$ \\
\hline 1 & $30-39$ & 14 & 56.0 \\
\hline 2 & $40-49$ & 7 & 28.0 \\
\hline 3 & $50-57$ & 4 & 16.0 \\
\hline \multicolumn{2}{|c|}{ Jumlah } & 25 & 100 \\
\hline
\end{tabular}

[13] Angkatan kerja dikategorikan produktif apabila berumur 15-54 tahun. Jika dilihat dari keseluruhan, petani yang melakukan usaha gula kelapa di Desa Sialang Jaya berada pada tingkat usia produktif sebanyak 23orang (92\%), sedangkan jumlah umur tidak produktif sebanyak 2 orang $(8 \%)$. Dengan banyaknya responden yang berumur produktif maka dapat disimpulkan bahwa petani usaha gula kelapa di daerah penelitian termasuk kedalam umur produktif. Hal ini merupakan salah suatu potensi fisik dan mental yang cukup baik untuk menjalankan usahataninya kearah yang lebih baik.

\subsubsection{Responden Berdasarkan Tingkat Pendidikan}

Pendidikan sangat mempengaruhi sikap dan daya fikir seseorang terutama dalam menerima inovasi baru untuk menjalankan suatu usaha agar memperoleh hasil yang lebih baik dengan memanfaatkan pendidikan yang dimiliki baik formal maupun informal. Tingkat pendidikan mempunyai pengaruh bagi pengusaha dalam melaksanakan kegiatan usahanya, terutama terhadap cara pengelolaannya. Kemampuan mengelola yang baik disebabkan karena wawasan dan pengetahuan yang dimiliki semakin banyak dan luas serta semakin terbuka terhadap inovasi yang dianjurkan. Adapun tingkat pendidikan responden tersaji pada Tabel 4

Tabel 4. Karakteristik Responden Berdasarkan Tingkat Pendidikan

\begin{tabular}{|c|c|c|c|}
\hline No & Pendidikan & Jumlah & $\begin{array}{c}\text { Persentase } \\
(\%)\end{array}$ \\
\hline 2 & SD & 10 & 40.0 \\
\hline 3 & SMP & 7 & 28.0 \\
\hline 4 & SMA & 8 & 32.0 \\
\hline & Jumlah & 25 & 100 \\
\hline
\end{tabular}

Sumber : Data primer diolah, 2018

Dari Tabel 4 diatas dapat dilihat bahwa tingkat pendidikan responden yang paling banyak adalah pada tingkat SD yaitu sebanyak 10 orang (40\%). Hal ini menunjukan bahwa tingkat pendidikan responden di daerah penelitian tergolong rendah dan perlu peningkatan pengetahuan baik secara pendidikan formal maupun nonformal. Menurut Mosher [6], keterbatasan pendidikan yang dimiliki seseorang dapat menjadi suatu kendala pembangunan yaitu cara berpikir serta mengambil keputusan. 


\subsubsection{Responden Berdasarkan Jumlah} Tanggungan Keluarga

Jumlah tanggungan keluarga merupakan merupakan total anggota keluarga yang terdiri dari suami, istri, anak dan lainnya yang termasuk ke dalam tanggungan keluarga. Jumlah tanggungan keluarga keluarga ressponden dapat dilihat pada Tabel 5.

Tabel 5. Karakteristik Responden Berdasarkan Jumlah Tanggungan Keluarga

\begin{tabular}{|c|c|c|c|}
\hline No & $\begin{array}{c}\text { Jumlah } \\
\text { Tanggungan }\end{array}$ & Jumlah & $\begin{array}{c}\text { Persentase } \\
(\%)\end{array}$ \\
\hline 1 & $1-2$ & 7 & 28.0 \\
\hline 2 & $3-4$ & 8 & 32.0 \\
\hline 3 & $5-6$ & 10 & 40.0 \\
\hline & Jumlah & 25 & 100 \\
\hline
\end{tabular}

Sumber : Data primer diolah, 2018

Pada Tabel 5 memperlihatkan bahwa jumlah tanggungan keluarga responden di daerah penelitian paling banyak yaitu 5-6 sebanyak 10 orang (40\%). Banyaknya jumlah anggota keluarga akan mempengaruhi aktivitas petani gula kelapa dalam mengelola usahanya. Jumlah tanggungan keluarga dapat dimanfaatkan sebagai tenaga kerja dalam keluarga agar dapat membantu dalam kegiatan usaha pengolahan gula kelapa

\subsubsection{Responden Berdasarkan Pengalaman Usaha}

Pengalaman usaha akan mempengaruhi keberhasilan yang dicapai oleh pengusaha. Semakin lama usaha yang dijalankan maka akan semakin banyak pengetahuan dan keterampilan yang diperolehnya. Pengalaman usaha memegang peranan penting dalam kegiatan usaha sehingga hasil yang diperoleh akan baik dan secara otomatis penghasilan yang diterima dari usaha gula kelapa akan semakin tinggi. Pengalaman usaha gula kelapa di Desa Sialang Jaya dapat dilihat pada tabel 6.

Tabel 6. Karakteristik Responden Berdasarkan Pengalaman Usaha

\begin{tabular}{|c|c|c|c|}
\hline No & $\begin{array}{c}\text { Pengalaman } \\
\text { Usaha }\end{array}$ & Jumlah & $\begin{array}{c}\text { Persentase } \\
(\%)\end{array}$ \\
\hline 1 & $3-7$ & 15 & 60.0 \\
\hline 2 & $8-11$ & 5 & 20.0 \\
\hline 3 & $12-15$ & 5 & 20.0 \\
\hline & Jumlah & 25 & 100 \\
\hline
\end{tabular}

Sumber: Data primer diolah, 2018

Pengalaman usaha responden berdasarkan Tabel 5 dapat dilihat bahwa mayoritas 3-7 tahun yaitu 15 orang (60.0\%). Data tersebut menunjukan bahwa responden didaerah penelitian ada yang sudah memiliki pengalaman dalam berusaha. [12] Semakin tinggi pengalaman usaha maka mereka sudah biasa menghadapi resiko dan mengetahui cara mengatasinya. Pengalaman usaha berpengaruh terhadap pengetahuan dan keterampilan pengusaha dalam menjalankan usahanya.

\subsection{Faktor - Faktor Produksi}

\subsubsection{Bangunan Tempat Mengolah Usaha}

Dalam menjalankan suatu usaha tentunya harus ada tempat agar usaha yang dilakukan dapat berjalan dengan lancar. Pada usaha pengolahan gula kelapa yang ada di Desa Sialang Jaya Kecamatan Batang Tuaka rata - rata pengusaha gula kelapa menggunakan tempat usahanya dengan membuat gubuk kecil sebagai tempat untuk pengolahan gula kelapa. Bangunan gubuk yang terbuat dari kayu dan atap daun rata-rata berukuran $3 \mathrm{~m} \times 4 \mathrm{~m}$.

\subsubsection{Modal}

Setiap usaha tentu membutuhkan modal untuk membiayai kegiatan operasional usaha sehari - hari baik untuk investasi maupun keperluan lainnya. Besarnya modal diperlukan akan berbeda sesuai dengan besar kecilnya skala usaha. [3] Modal merupakan unsur pokok dalam suatu usaha yang digunakan untuk merubah pendapatan, modal usaha diklarifikasikan sebagai kekayaan utama baik dalam bentuk uang maupun barang yang digunakan untuk menghasilkan sesuatu secara langsung maupun tidak langsung dalam proses produksi. Modal pada usaha pengolahan gula kelapa antara lain bahan baku, pengemasan, alat produksi dan bahan bakar yang akan dijelaskan sebagai berikut :

a. Bahan Baku

Bahan baku merupakan bahan mentah yang menjadi dasar pembuatan suatu produk yang mana bahan tersebut dapat diolah melalui proses tertentu untuk dijadikan wujud yang lain. Bahan baku dari gula kelapa adalah nira kelapa, dimana pohon kelapa akan disadap kemudian diambil niranya. Pohon kelapa yang disadap niranya pada usaha pengolahan nira kelapa di Desa Sialang Jaya mayoritas pohon kelapa milik petani sendiri dan berusia diatas 5 tahun

b. Peralatan

Peralatan merupakan alat - alat yang digunakan dalam melakukan proses produksi. Pada proses pengolahan gula kelapa alat produksi yang digunakan yaitu parang, sabit, kuali, sendok pengaduk, cetakan bambu, saringan, toples, ember, dan timbangan 
c. Pengemasan

Pengemasan merupakan suatu cara atau perlakuan pengamanan terhadap makanan atau bahan pangan, agar makanan atau bahan pangan baik yang belum diolah maupun yang telah mengalami pengolahan, dapat sampai ke tangan konsumen dengan selamat secara kuantitas maupun kualitas.Pengemasan pada usaha pengolahan gula kelapa yaitu plastik untuk membungkus gula kelapa yang telah jadi,plastic yang digunakan yaitu plastik putih bening ukuran $25 \mathrm{~kg}$, dan dalam satu plastik biasanya diisi gula kelapa sebanyak $20 \mathrm{~kg}$ perplastik. Kemudian menggunakan tali untuk mengikat plastik gula kelapa, dan menggunakan asoy besar untuk dikemas setelah dimasukan dalam plastik.

d. Bahan Bakar

Bahan bakar yang digunakan yaitu kayu bakar. Pada proses produksi pengolahan gula kelapa menggunakan kayu bakar dan sabut kelapa. Umumnya pada saat produksi gula kelapa kayu bakar yang dibutuhkan yaitu sebanyak 1 ikat kayu bakar yang dapat digunakan untuk 5 kali produksi.

e. Tenaga Kerja

Tenaga kerja adalah semua orang yang bersedia untuk sanggup bekerja [13]. Artinya bahwa semua orang yang melakukan kegiatan pekerjaan untuk diri sendiri atau orang lain tanpa menerima upah atau mereka yang sanggup bekerja. Pada usaha pengolahan gula kelapa yang ada di Desa Sialang Jaya, para produsen gula kelapa hanya menggunakan tenaga kerja dalam keluarga, yaitu yang terdiri dari suami dan istri.

\subsection{Teknik Pengolahan Gula Kelapa}

Proses pembuatan gula kelapa pada prinsipnya adalah proses penguapan atau pemekatan nira. Tahap-tahap proses pembuatan gula kelapa meliputi:

a. Pengumpulan Nira

Nira hasil sadapan dikumpulkan dalam ember, lalu sesegera mungkin dimasak untuk mencegah terbentuknya asam. Sisa pengawet yang mengumpul di ujung pongkor tidak diikutkan karena akan menghasilkan warna gula yang kurang baik.

b. Penyaringan

Sebelum dimasak, nira disaring terlebih dahulu untuk membuang kotoran-kotoran berupa bunga kelapa, lebah dan semut. Penyaringan ini menggunakan kain saring yang bersih. c. Pemasakan

Dilakukan pemasakan nira pada suhu 1100C. pada saat mulai mendidih, kotoran halus akan terapung ke permukaan bersama-sama buih nira. Pendidihan selanjutnya akan menimbulkan busa nira yang meluap-luap berwarna coklat kekunging-kuningan. Bila nira sudah mengental, api dikecilkan dan pekatan nira tetap diaduk-aduk. Untuk mengetahui bahwa nira tersebut sudah masak atau belum, dilakukan pengujian kekentalan yaitu dengan cara menteskan pekatan nira ke dalam air dingin. Bila tetasan tadi menjadi keras, pemasakan sudah cukup dan wajan segera diangkat dari tunggu. Waktu yang diperlukan untuk memasak 25-30 liter nira kira-kira 4-5 jam.

d. Pendinginan

Untuk mempercepat proses pendinginan, pekatan nira dilakukan pengadukan. Pengadukan dilakukan sampai suhunya turun menjadi sekitar 700C. pengadukan ini juga akan menyebabkan tekstur dan warna gula yang dihasilkan lebih baik dan cepat kering.

e. Pencetakan

Segera setelah suhu pekatan nira telah turun menjadi sekitar 700C, maka dilakukan pencetakan. Pekatan nira dituangkan ke dalam cetakan bambu yang sebelumnya telah direndam dan dibasahi dengan air untuk mempermudah pelepasan setelah gula menjadi kering.

f. Pengemasan

Gula yang telah dikeluarkan dari cetakan dibungkus untuk selanjutnya dipasarkan. Pembungkus yang digunakan dapat berupa daun kelapa kering, pohon pisang atau kantung plastik.

\subsection{Biaya Produksi}

Biaya produksi merupakan biaya yang dikeluarkan oleh pengusaha gula kelapa selama melakukan kegiatan usahanya dimulai dari proses produksi hingga menghasilkan produk, yang meliputi biaya tetap dan biaya tidak tetap. Biaya tetap adalah biaya yang relatif tetap jumlahnya, dan terus dikeluarkan walaupun produksi yang diperoleh banyak atau sedikit sedangkan biaya tidak tetap adalah biaya yang besar kecilnya dipengaruhi oleh produksi yang diperoleh.

Pada usaha pengolahan gula kelapa di Desa Sialang Jaya biaya tidak tetap terdiri dari bahan baku yaitu nira kelapa, biaya pengemasan yaitu plastik, karet, , dan asoy besar, kemudian bahan bakar, yang terakhir yaitu biaya tenaga kerja dalam keluarga. 
Sedangkan biaya tetap terdiri dari biaya penyusutan alat yang terdiri dari parang, sabit, kuali, sendok pengaduk, cetakan bambu, saringan, toples, ember dan timbangan. Rincian biaya produksi yang dikeluarkan dalam usaha pengolahan gula kelapa di Desa Sialang Jaya dapat dilihat pada Tabel 7 .

Tabel 7. Analisis Biaya Produksi Usaha Pengolahan Gula Kelapa Per Produksi

\begin{tabular}{|c|c|c|c|c|}
\hline No & Biaya & $\begin{array}{c}\text { Satua } \\
n\end{array}$ & $\begin{array}{l}\text { Harga } \\
(\mathrm{Rp})\end{array}$ & $\begin{array}{c}\text { Jumlah } \\
\text { (Rp) }\end{array}$ \\
\hline \multirow[t]{12}{*}{1} & Biaya Tidak Tetap & & & \\
\hline & a. Bahan Baku & & 700 & $25.480,00$ \\
\hline & b. Bahan Pengemasan & & & \\
\hline & i.Plastik & $\mathrm{Kg}$ & 1.000 & 650,00 \\
\hline & ii.Tali & Ikat & 1.000 & 173,20 \\
\hline & iii.Asoy Besar & $\begin{array}{l}\text { Bungk } \\
\text { us }\end{array}$ & 1.000 & 840,00 \\
\hline & c. Bahan Penunjang & & & \\
\hline & i. Resak & $\mathrm{Kg}$ & 17.500 & 9333,33 \\
\hline & ii.Pengawet & $\begin{array}{c}\text { Bungk } \\
\text { us }\end{array}$ & 6.000 & $2.136,00$ \\
\hline & d. Bahan Bakar & $\mathrm{Rp}$ & & $2.626,67$ \\
\hline & e. Biaya Transportasi & $\mathrm{Rp}$ & & $3.733,33$ \\
\hline & f. $\quad$ Biaya Tenaga Kerja & $\mathrm{Rp}$ & & $30.000,00$ \\
\hline \multirow{3}{*}{2} & Jumlah & & & $66.572,53$ \\
\hline & Biaya Tetap & & & \\
\hline & Penyusutan Alat & $\mathrm{Rp}$ & & 779,44 \\
\hline & Total & & & $67.351,97$ \\
\hline
\end{tabular}

Sumber : Data primer diolah, 2018

Biaya tidak tetap adalah biaya yang sifatnya berubah - ubah tergantung dari besar kecilnya produksi yang dihasilkan [12]. Biaya variabel dalam dalam usaha pengolahan gula kelapa terdiri dari biaya bahan baku, biaya pengemasan, dan biaya tambahan yeng terdiri dari bahan bakar dan biaya transportasi. Pada Tabel 6 menunjukkan bahwa biaya tidak tetap dari usaha pengolahan gula kelapa di Desa Sialang Jaya terdiri dari biaya bahan baku sebesar Rp. $25.480,00$ bahan baku yaitu nira kelapa. Biaya pengemasan yang terdiri dari plastik sebesar Rp. 650,00, tali sebesar Rp. 173,20, dan asoy besar yaitu sebesar Rp. 840,00, biaya bahan bakar sebesar Rp. 2.626,67, biaya trasnportasi sebesar Rp. 3.733,33 dan yang terakhir adalah biaya tenaga kerja sebesar Rp. 30.000,00. Maka dari itu dapat diketahui biaya tidak tetap sebesar Rp. $66.572,53$ per per produksi.

Biaya tetap adalah biaya yang relatif jumlahnya dan harus dikeluarkan walaupun produk yang dihasilkan banyak atau sedikit [11]. Pada Tabel 6 menunjukan bahwa biaya tetap terdiri dari biaya penyusutan alat per produksi sebesar Rp779,44. Biaya penyusutan ini dihitung dari masing - masing peralatan yang ditentukan oleh banyaknya masing - masing alat yang digunakan dan umur ekonomisnya. Biaya penyusutan yang dimaksud disini adalah penyusutan alat-alat yang digunakan dalam pengolahan gula kelapa, terdiri dari parang, sabit, kuali, sendok pengaduk, cetakan bambu, toples, ember dan timbanganBiaya penyusutan yang dihitung pada usaha ini dihitung dalam periode per bulan.

[12] Total biaya adalah keseluruhan biaya tetap ditambah dengan biaya tidak tetap. Biaya total merupakan biaya yang dikeluarkan oleh pengusaha gula kelapa secara keseluruhan. Dari tabel 6 memperlihatkan bahwa total biaya usaha pengolahan gula kelapa di daerah penelitian adalah rata-rata sebesar Rp. 67.351,97 per produksi, dimana jumlah biaya tidak tetap rata-rata sebesar Rp. 66.572,53 dan biaya tetap sebesar Rp. 779,44 per produksi. Satu kali produksi memerlukan waktu satu hari. Dapat disimpulkan bahwa biaya yang berkontribusi besar adalah biaya tidak tetap.

\subsection{Penerimaan}

Penerimaan usaha agroindustri adalah perkalian antara jumlah produksi yang diperoleh dengan harga yang berlaku dipasar [12]. Penerimaan yang diperoleh yaitu ratarata sebesar Rp.202.800,00 per produksi. Penerimaan diperoleh dari harga gula kelapa rata- rata Rp. $13.000 / \mathrm{kg}$ dikalikan dengan jumlah produksi gula kelapa rata-rata yaitu $390 \mathrm{~kg}$ per produksi.

\subsection{Keuntungan}

Komposisi penerimaan, keuntungan dan efisiensi usaha pengolahan gula kelapa di Desa Sialang Jaya yang tersaji pada Tabel 8. Tabel 8. Komposisi penerimaan dan keuntungan usaha pengolahan gula kelapa di Desa Sialang Jaya Kecamatan Batang Tuaka Per Produksi

\begin{tabular}{|c|l|r|}
\hline No. & \multicolumn{1}{|c|}{ Uraian } & \multicolumn{1}{c|}{ Jumlah (Rp) } \\
\hline 1. & Total Biaya & $202.800,00$ \\
\hline 2. & Penerimaan & $135.448,03$ \\
\hline 3. & Keuntungan & $166.227,47$ \\
\hline 4. & $\begin{array}{l}\text { Pendapatan Kerja } \\
\text { Dalam Keluarga }\end{array}$ & \\
\hline
\end{tabular}

Sumber : Data primer diolah, 2018

Keuntungan yang diperoleh usaha pengolahan gula kelapa di Desa Sialang Jaya merupakan selisih antara total penerimaan dengan total biaya yang dikeluarkan. Untuk mengetahui besarnya keuntungan pada usaha pengolahan gula kelapa di Desa Sialang Jaya dapat dilihat pada tabel 8 yang menunjukan bahwa keuntungan yang diperoleh sebesar Rp. 135.448,03 per produksii. [3] Berhasil tidaknya usaha dapat dilihat dari besarnya pendapatan yang diperoleh dalam mengelola suatu usaha. Bagi pengusaha analisis ini membantu mereka dalam mengukur apakah kegiatan usaha mereka pada saat ini berhasil atau tidak. 


\subsection{Pendapatan Kerja Dalam Keluarga}

Pendapatan kerja keluarga merupakan imbalan terhadap bunga harta sendiri, upah tenaga kerja keluarga, dan besarnya penghasilan yang di peroleh. Pada tabel 8 dapat dilihat bahwa jumlah pendapatan kerja dalam keluarga rata- rata sebesar Rp166.227,47 per hari. Pendapatan kerja keluarga diperoleh dari pendapatan bersih ditambah dengan upah tenaga kerja dalam keluarga dan penyusutan alat. Besarnya pendapatan tenaga kerja dalam keluarga pada usaha pengolahan gula kelapa dikarenakan banyaknya jumlah curahan tenaga kerja dalam keluarga yang digunakan pada usaha ini. Menurut Tohir (1983), keberhasilan atau kesuksesan usaha dapat dilihat daru sudut ekonomi yaitu besarnya penghasilan atau pendapatan kerja keluarga.

\subsection{Nilai Tambah}

Nilai tambah didapat dari besarnya nilai akhir dari produksi gula kelapa dikurangi dengan besarnya nilai bahan baku dan sumbangan input lain. Analisis nilai tambah berguna untuk mengetahui berapa tambahan nilai yang terdapat pada suatu output yang dihasilkan. Nilai tambah usaha agroindustri gula kelapa Di Desa Sialang jaya Kecamatan Batang Tuaka Kabupaten Indragiri Hilir dapat dilihat pada tabel 9.

Tabel 9 menunjukan bahwa produksi gula kelapa dalam sekali produksi rata-rata adalah $15,60 \mathrm{~kg}$. Dalam menghasilkan produk tersebut diperlukan bahan baku nira sebanyak 36,40 liter. Dengan demikian faktor konversi untuk gula kelapa adalah 0,43 yang artinya dari 100 liter nira akan dihasilkan 43 kg gula kelapa. Jumlah tenaga kerja yang digunakan rata-rata adalah 2 orang. Angka koefisien tenaga kerja yang diperoleh adalah 0,05 .

Nilai produksi kopra adalah Rp. 5.571,43 per $\mathrm{kg}$ (diperoleh dari hasil kali antara faktor konversi dengan harga gula kelapa). Nilai tambah yang diperoleh adalah Rp. 4.672,76. Hasil ini senada dengan penelitian Fahrun Umar [2] dimana nilai tambah per bahan baku yang dinikmati usaha gula kelapa di Desa Bonedaa sebesar Rp. 4.428,03. Nilai tambah diperoleh dari pengurangan nilai produk dengan harga bahan baku dan nilai input lain. Rasio nilai tambah yang diperoleh adalah sebesar 83,87 persen. Rasio nilai tambah menunjukkan bahwa setiap Rp.100,00 dari nilai produk mendapatkan nilai tambah rata-rata Rp. 83,87. Pada penelitian Arnita [1] di Desa Mumpa Kecamatan Tempuling Kabupaten Indragiri
Hilir, pengolahan gula kelapa memberikan nilai tambah sebesar Rp. 1.815,58.

Imbalan tenaga kerja yang diperoleh dari hasil kali antara koefisien tenaga kerja dengan upah tenaga kerja yaitu Rp. 1.648,35 per kg. Persentasi pangsa tenaga kerja terhadap nilai tambahnya adalah 35,28 persen. Imbalan terhadap modal dan keuntungan diperoleh dari nilai tambah dikurangi besar imbalan tenaga kerja. Keuntungan dari pengolahan kopra dalah sebesar Rp. 3.024,41 per kg dengan tingkat keuntungan 64,72 persen.

Tabel 9. Analisis Nilai Tambah pada Usaha Pengolahan Gula Kelapa

\begin{tabular}{|c|c|c|}
\hline No. & Variabel & $\begin{array}{c}\text { Nilai } \\
\text { Produksi }\end{array}$ \\
\hline \multicolumn{3}{|c|}{ Output, Input dan Harga } \\
\hline 1 & $\begin{array}{l}\text { Hasil produksi gula kelapa } \\
(\mathrm{kg})\end{array}$ & 15,60 \\
\hline 2 & Bahan baku nira (liter) & 36,40 \\
\hline 3 & Tenaga kerja (orang) & 2,00 \\
\hline 4 & Faktor konversi & 0,43 \\
\hline 5 & Koefisien tenaga kerja & 0,05 \\
\hline 6 & Harga gula kelapa $(\mathrm{Rp} / \mathrm{kg})$ & $13.000,00$ \\
\hline 7 & $\begin{array}{l}\text { Upah tenaga kerja } \\
\text { (Rp/orang) }\end{array}$ & $30.000,00$ \\
\hline \multicolumn{3}{|c|}{$\begin{array}{l}\text { Penerimaan dan } \\
\text { Keuntungan }\end{array}$} \\
\hline 8 & Harga nira (Rp/liter) & 700,00 \\
\hline 9 & $\begin{array}{l}\text { Sumbangan input lain } \\
(\mathrm{Rp} / \mathrm{kg})\end{array}$ & 198,67 \\
\hline 10 & $\begin{array}{l}\text { Nilai produksi gula kelapa } \\
(\mathrm{Rp} / \mathrm{kg})\end{array}$ & $5.571,43$ \\
\hline $11 \mathrm{a}$ & Nilai tambah (Rp/kg) & 4.672 .76 \\
\hline $11 \mathrm{~b}$ & Rasio nilai tambah(\%) & 83,87 \\
\hline $12 a$ & $\begin{array}{l}\begin{array}{l}\text { Imbalan tenaga kerja } \\
(\mathrm{Rp} / \mathrm{kg})\end{array} \\
\end{array}$ & $1.648,35$ \\
\hline $12 b$ & Pangsa tenaga kerja (\%) & 35,28 \\
\hline $13 a$ & Keuntungan (Rp/kg) & $3.024,41$ \\
\hline $13 b$ & Tingkat keuntungan (\%) & 64,72 \\
\hline
\end{tabular}

Sumber : Data Primer Diolah, 2018

\section{KESIMPULAN DAN SARAN}

\subsection{Kesimpulan}

Dari uraian dan penjelasan yang telah dikemukakan dalam hasil penelitian ini maka dapat disimpulkan sebagai berikut :

a. Rata-rata penerimaan yang diperoleh sebesar Rp. 202.800,00 per produksi, sedangkan rata-rata total biaya yang dikeluarkan adalah sebesar Rp. 67.351,97 per produksi sehingga diperoleh keuntungan rata-rata sebesar Rp. 135.448,03 per produksi.

b. Pengolahan gula kelapa memberikan nilai tambah sebesar Rp. $4.672,76$ per $\mathrm{kg}$. Rasio nilai tambah yang diperoleh adalah sebesar 83,87 \%. Keuntungan dari pengolahan gula kelapa adalah sebesar Rp. 3.024,41 per $\mathrm{kg}$ dengan tingkat keuntungan 64,72\%. 


\subsection{Saran}

a. Pengusaha gula kelapa hendaknya lebih meningkatkan jumlah produksi agar mendapatkan keuntungan maksimal.

b. Pengusaha gula kelapa lebih memperhatikan kualitas gula kelapa agar nilai tambah produk dapat meningkat.

c. Produksi gula kelapa dalam penelitian ini masih menggunakan alat atau teknologi yang sederhana sehingga pelaku industri memakan waktu yang lama dalam mengolah gula kelapa tersebut, oleh karena itu disarankan untuk menggunakan teknologi yang lebih canggih sehingga dapat mengefisienkan waktu dan biaya dalam mengolah gula kelapa.

\section{DAFTAR PUSTAKA}

[1] Arnita, 2017. Analisis Nilai Tambah Produk Turunan Kelapa Di Desa Mumpa Kecamatan Tempuling Kabupaten Indragiri Hilir. Jurnal Agribisnis. 8(2): 119-132.

[2] Fahrun Umar, 2015. Analisis Nilai Tambah Industri Rumah Tangga Gula Kelapa Di Desa Bonedaa Kecamatan Suwawa Selatan Kabupaten Bone. Skripsi. Program Studi Agribisnis Universitas Negeri Gorontalo. Gorontalo.

[3] Hayami, Kawagoc, Marooka, Siregar. 1987. Agricultural Marketing and Processing In Upland Java. A Perspective From a Sunda Village, CGPRT. Bogor.

[4] Hernanto F. 1991. Ilmu Usahatani.Penebar Swadaya. Jakarta

[5] Lipsey dan Steiner, 1986. Pengantar IImu Mikro Ekonomi. Grand Media. Jakarta.

[6] Mosher A.T. 1985. Pembangunan Pertanian. Penerbit LP3ES.Jakarta.

[7] Mulyadi. 1995. Akutansi Biaya, Edisi kelima, FE Universitas Gajah Mada.Yogyakarta.

[8] Rahim, 2007. Pengantar, Teori dan Kasus Ekonomika Pertanian. Penebar Swadaya. Jakarta

[9] Santoso,U. 2000. Pengembangan Penelitian Pemanfaatan Kelapa Sebagai Bahan Pangan (Focus Of Research On Coconut As Food). Seminar Nasional Industry Pangan. Fakultas Teknologi Pertanian Universitas Gadjah Mada. Yogyakarta.

[10] Setyamidjaja, D. 1984. Bertanam Kelapa. Penerbit Kanisius, Yogyakarta.

[11]Soedjarwanto dan Riswan., 1994. Penyerapan Tenaga Kerja pada Industri Batu Bata di Kabupaten Dati II
Banyumas. Skripsi. Fakultas Ekonomi UNSOED. Purwokerto.

[12] Soekartawi. 1998. AnalisisUsahatani. UIPress, Jakarta.

[13] Simanjuntak PJ. 1996. Pengantar Ekonomi Sumber Daya Manusia. Fakultas Ekonomi. Universitas Indonesia. Jakarta

[14] Soemarso S.R, 2004, Akuntansi Suatu Pengantar. Edisi Lima. Salemba Empat.Jakarta.

[15] Zmimerer, W. Thomas M. Scarborough. 1996. Entreppreneurship and The New Venture Formation. New Jersey : Prentice Hall International Inc. 